\title{
THE ISLAMIC MODERATION AND THE PREVENTION OF RADICALISM AND RELIGIOUS EXTREMISM IN INDONESIA
}

\author{
SUBHAN Hi ALI DODEGO*, DOLI WITRO** \\ *Institut Agama Islam Negeri Ternate, Jl. Lumba-Lumba No. RT 001/03, Dufa Dufa, Ternate Utara, Kota Ternate, Maluku Utara, \\ Kode Pos 97727. Email: subhandodego03@gmail.com dan **UIN Sunan Gunung Djati Bandung, JI. A. H. Nasution No. 105, \\ Cipadung, Kecamatan Cibiru, Kota Bandung, Jawa Barat, Kode Pos 40614 Email: doliwitro01@gmail.com
}

\begin{abstract}
Radical and extremist groups' actions are totally opposite to the Islamic teachings. In warding off the radical movements and terrorism, an open concept of inclusive religious understandings are needed. This concept is known as religious moderation. This study aims to explore efforts in reducing the massive movement of radicalism and intolerance in the frame of basic religious practices. This qualitative study relies upon the literature research where data reduction, data presentation, and concluding are employed. The results showed that Islamic moderation is reflected in the moderate attitudes. Religious moderation stems from tolerance, peace, and harmony within a multi-religious society.
\end{abstract}

KeY WoRDS: Islamic moderation, radicalism, extremism

\section{MODERASI ISLAM SEBAGAI SOLUSI MENANGKAL GERAKAN RADIKALISME DAN EKSTRIMISME AGAMA DI INDONESIA}

\begin{abstract}
Abstrak
Kelompok radikalisme dan ektrimisme telah melakukan tindakan yang sangat bertentangan dengan ajaran Islam. Oleh karena itu, untuk menangkal gerakan radikal dan terorisme diperlukan sebuah konsep beragama yang bersifat terbuka (inklusif). Konsep beragama yang inklusif ini disebut dengan moderasi beragama. Penelitian ini bertujuan untuk meredam dan meminimalisir masifnya gerakan radikalisme dan intoleransi maka dibutuhkan konsep beragama yang sederhana, tidak kaku dan mudah dipahami oleh masyarakat umum. Penelitian ini merupakan penelitian kualitatif yang bersifat penelitian pustaka. Penulis menggunakan metode analisis data yaitu reduksi data, penyajian data, dan penarikan kesimpulan. Hasil penelitian menunjukkan moderasi Islam atau moderasi beragama merupakan sikap hidup yang berada di tengah, tidak condong ke kiri, kanan, ke depan dan ke belakang, tetapi berada di tengah dalam melihat dan menyelesaikan sebuah persoalan. Akhirnya, muara dari moderasi beragama yaitu menciptakan suasana yang toleran, damai dan harmonis di tengah kehidupan yang serba multiagama dan multikultural.
\end{abstract}

KATA KUNCI: moderasi Islam, radikalisme, ekstremisme

\footnotetext{
*Naskah diterima Juli 2020, direvisi September 2020, dan disetujui untuk diterbitkan November 2020
} 


\section{A. Introduction}

At present, the Indonesian people are faced with a situation of increasing intolerance, radicalism, terrorism, and violent extremism. The phenomenon of intolerance occurs in various regions of Indonesia, along with an increase in identity politics. To begin with, young people are exposed to religious news that contains hatred and suspicion marked by the ease of opposing and denying the fulfillment of citizenship rights to groups that are disliked until finally committing radical actions (Mulia, 2018). There are some strong indications that radical religious understandings and actions leading to acts of terrorism have begun to target educated young groups in recent years. Including those who are students and even students. In connection with the increasing number of young groups involved in terrorism networks, it is increasingly apparent that universities and schools are increasingly vulnerable to such movements' influence. By spreading extreme religious understanding patterns, some students and students have been successfully influenced to the point of falling into acts of terrorism (Mubarak, 2014).

When viewed from social facts on the ground, acts of terrorism committed by extremist groups are numerous. For example, acts of terrorism that once shook Indonesia in particular and the world in general (Siradj, 2013; Yanti \& Witro, 2019, 2020) are the bombing in Kuningan, JW Marriot, and the Bali bombing. Data prove that within the 2016 terrorist acts can be identified, namely the Thamrin bomb (January 14), the abolition of the Surabaya terror plan (June 8), the Surakarta Mapolresta bomb (July 5), the Batam terror action plan (August 5), the Medan Gerja terror act ( 28 August), Samarinda Church terror (13 November), threatening vital state objects (23 November), palace bomb plan (10 December), Solo terror act (15 December), planned blasting in Bali (18 December) (Susanto, 2018).

Furthermore, in a broader context, the factors influencing the rise of radicalism in Indonesia are influences the Islamic State of Iraq and Syria (ISIS) in the international realm. Then in the national sphere, the influence of the emergence of radical religious organizations includes Mujahidin Indonesia Timur (MIT), Majelis Mujahidin Indonesia (MMI), Negara Islam Indonesia (NII), dan Jamaah Islamiyah (JI). These organizations are suspected of being involved in movements that lead to acts of radicalism and terrorism (Alam, 2017).

The above phenomenon proves that radicalism and extremism groups have taken actions contrary to Islamic teachings. Islam is a religion that carries a moral message and promotes the value of peace and humanity. So that in the context of Indonesian terrorism and radical movements, it is very contrary to the values of Pancasila and the 1945 Constitution.

Radicalism can be said to be one of the attitudes that want total and revolutionary change by distorting existing values drastically through violence and extreme actions. Among the characteristics of radical and intolerant attitudes, namely, first, people who understand intolerance do not want to respect others' opinions and beliefs. Second, intolerant people tend to be fanatical, consider themselves right, and assume others are wrong. Third, intolerant people tend to think exclusively of differentiating themselves from Muslims in general. Fourth, people who have an intolerant understanding tend to think revolutionary, namely tend to use violent methods to achieve goals (Sa'adah, 2019).

Therefore, to ward off radical movements and terrorism, an open concept of religion (inclusive) is needed. The concept of inclusive religion is called Islamic moderation or also called religious moderation. That is why this religious moderation movement is worth campaigning to the broader community. This notion of religious moderation emerged as a concrete step to counteract the radicalism and intolerance movements (Wibowo, 2019). Therefore, to reduce and minimize the massive movements of radicalism and intolerance, a simple religious concept that is not rigid and easily understood by the general public is needed. That is the moderation of Islam, the religious concept adopted by someone who is not biased, is in the middle to reconcile the flow of radicalism and secularism.

\section{B. Research Methods}

This study used a qualitative approach, in which the data obtained were not written in numbers, but in a qualitative form, its nature provides analysis and presentation of the object understudy in the form of narration (Margono, 2007; Sugiono, 2009). This research is library 
research where data sources are obtained from books, journals, magazines, scientific articles, and the internet. Data is collected by reading, analyzing, and analyzing as much as possible obtained from the data source. In analyzing the data, the writer uses Miles and Huberman's data analysis methods, namely data reduction, data presentation, and conclusion drawing (Miles \& Huberman, 1984).

\section{Results and Discussion Genealogy Roots and Meaning of Islamic Moderation}

In Kamus Besar Bahasa Indonesia (KBBI), the term moderation means the tendency to be at the midpoint between two extreme poles. Hashim Kamali stated, in Islam, moderation is an essential aspect because it has many ramifications in various fields, which is quite impressive in Islamic studies. Kamali also explained religious moderation related to current moral virtues related to the life of each individual and related to the nation and State (Rohimah, 2019).

In Arabic, the term moderation is known as al-wasathiyah. In al-wasathiyah language, derived from the word wasath. Al-Asfahaniy interprets wasath with sawa'un, which is in the middle between two boundaries, or with justice in the middle (Mussafa, 2018). Then wasathan also means to guard against being uncompromising or leaving religious truth. Departing from this understanding, Islamic moderation, both in terms of language and terms, has an exact source or foundation. The word Islam moderation is also found in the Al-Quran surah al-Baqarah verse 143:

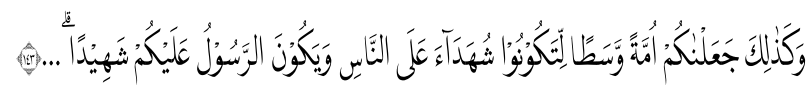

Meaning: And thus we have made you a just community that you will be witnesses over the people, and the Messenger will be a witness over you (Departemen Agama RI, 2010).

The word wasath has a fair meaning. Then the word wasath, when interpreted as moderate, means pluralism. Diversity in various conditions in Indonesia is very much needed. It is a comprehensive religious teaching system that can represent every person through flexible teaching by not leaving the Al-Quran and al-Hadith text and the importance of using its reason as a solution to every problem that exists. The condition of Indonesia's pluralism has existed for a long time in terms of religion, ethnicity, culture, and language. Islam in Indonesia utilizes local wisdom to create harmony between religious communities (Fauzi, 2018).

According to Ibn 'Asyur the word wasath has two meanings. First, etymologically the word wasath means something in the middle of something with two ends of equal size. Secondly, understanding in terminology, the word wasath is the values of Islamic teachings built based on a straight and centered mindset, not excessive in doing an action ('Asyur, 1984). In line with this, as Aristotle quoted by M. Quraish Shihab, the nature of virtue is the middle between two despicable traits. This is how the word wasath is attached to kindness so that the perpetrators of goodness themselves are also named wasath with the understanding of good people. Therefore, he is always fair in giving decisions and testimonies (Shihab, 2016).

Therefore, Islamic moderation is an attitude that tends to justice and commendable action. People who in life are not exaggerating can be said to be a moderate class. In other words, Islamic moderation can shape one's mindset, attitude, and behavior to love peace and justice. In everyday life, it is clear that people who think moderate will be tolerant and tend to be open to their community.

\section{Understanding the Meaning of Radicalism in Indonesia}

The word radicalism is taken from Latin, the radix, which means root, base, bottom, or it can also be comprehensive, all-out, and tough to demand change. Whereas in the Big Indonesian Dictionary (KBBI), radicalism is said to have meaning: first, radical understanding or flow in politics. Second, understandings or streams that want social or political change or renewal using violence or drastic. Third, extreme attitudes in the flow of politics (Munip, 2012).

In Arabic, the term radicalism can be understood, including al-'unf, at-tatarruf, and algulluw. The word al-'unf is an act of violence that uses force unofficially (illegally) to impose its will and opinion. The term al-tatarruf is taken from the word al-tarf, which means "edge". This means that someone is in the edge or edge position, both at 
the left and right ends. Therefore, al-tatarrufal-dini means all excessive actions in religion, which is the opposite of the word al-wasath "middle or moderate," which has excellent and praiseworthy meaning (Zuhdi, 2017).

Radicalism can be understood as referring to extreme ways of thinking and acting. Someone defined as "radical" rejects what already exists and wants to replace it with something new. The desired change is (usually) extreme because the traditions and situations that develop, in which a radical ideology lives, are considered enemies that must be destroyed. Therefore, radicalism rejects all forms of compromise. Put merely, and radicalism leads to blaming (blaming) whatever is and has existed. The approach used in looking at problems is usually black and white (Mubarak, 2014).

Stated, people exposed to radicalism can be divided into two levels, namely the level of thought and the level of physical activity. At the first level, radicalism is still in the stage of discourse, concepts, and ideas discussed, all of which lead to supporting the use of violent means to achieve specific goals. People have started taking action with their actions in the socio-political and religious fields at this second level. At the political level, this understanding begins to appear from the act of legitimizing his opinion in radical ways, even to the act of mobilizing the masses for specific political interests and leading to social conflicts. (Munip, 2012).

According to Yusuf Qardhawi, radicalism is an excessive attitude possessed by a person in religion, there is a mismatch between faith and behavior, between what should be with reality, between religion and politics, between speech with action, between imagined and implemented, and between the law prescribed by Allah with the product of human law itself (Al-Qaradhawi, 2014).

The Minister of Religion of the Republic of Indonesia (FRI), Fachrul Razi, explained that there are four elements of radicalism, ranging from intolerance to liking other people. Four elements include: first, intolerance with other people who are different, denying the sociological facts of diversity. Second, there is the concept of takfiri, which disbelieves or blames others outside the group. Third, imposing the will with various propositions, including misinterpreted religious propositions, and fourth, the ways of violence, both verbal and physical (Saronji, 2014).

According to the former Head of the National Intelligence Agency (BIN), Hendropriyono said that radicalism was the embryo of the birth of terrorism. Radicalism is one of the attitudes that wants a change in totality and is revolutionary by reversing the values that exist drastically through violence (violence) and extreme actions. Hendro Priyono said that several characteristics could be recognized from radical attitudes and understandings. First, intolerance (do not want to respect the opinions and beliefs of others). Second, fanatical (always feels right himself; think others are wrong). Third, exclusive (distinguish themselves from Muslims in general). Fourth, revolutionary (tend to use violent means to achieve goals) (Abby, 2019).

From this, it can be seen that radicalism is an understanding that wants change precisely and quickly but through violence. If you look at Islam's teachings, indeed, no order will be found to make the damage even more violence in the name of religion. The commands of Islamic teachings all lead to an attitude of tolerance, peace, and harmony. If it is seen that individuals or groups are acting in the name of Islam and deliberately carrying out acts of violence such as using weapons, then carrying out suicide bombings, it is an act of terror and extremism and not from Islamic teachings.

\section{Islamic Moderation as a Solution to Prevent Radicalism and Extremism}

Talking about religious moderation in the Indonesian context is very important. Because lately, the Indonesian nation's existence began to be undermined and undermined by radical and extremist understandings, which indirectly had threatened the safety of the Indonesian nation. It might even be said that Indonesia was not yet free from intolerant acts and radicalism at this time. In several areas, suicide bombings have occurred because of a shallow and narrow understanding of Islam about Al-Quran and Hadith's teachings.

According to Azyumardi Azra, to build harmonious relations between religious communities and create an inclusive atmosphere in religion. Then it takes the ability of each religious group. To deepen understanding other denominations' doctrines and practices as a priority (Yunus \& Salim, 2018). The mutual 
relationship in question is how each religion's understanding of its teachings without blaming each other between different groups so that the atmosphere of relations between religions can run well and create an atmosphere that is tolerant and harmonious.

History has noted that the clashes or friction between religions in Indonesia, especially between Islam and Christianity, always start from the closure of each party about what is scheduled in da'wah (Islam) or mission (Christian), and both do not try to sit together (Rumadi, 2014). Barbara Brown Zikmund "president of Hartford Seminary" said at a study center between religions in Connecticut, the United States, Islam, and Christianity, had great attention to the mission (da'wah), and at that point, both of them often collided (Madjid, 2004). From this, the concept of openness in religion needs to be glanced at again, and it is time to come upon the surface.

Because of the importance of religious tolerance as a means for mutual acceptance of one another, the Indonesian government through the Ministry of Religion of the Republic of Indonesia, in 1971-1978, succeeded in forming the Harmony of Life project among Religious Communities, which organized dialogues between religious leaders. The Department of Religion also forms a forum for deliberation between religious communities, regularly held joint meetings such as the Forum for Religious Harmony (FKUB) (Mubarok, 2014a). This forum was formed together with the Indonesian Ulema Council (MUI) Association of Churches in Indonesia (PGI), Conference of Trustees of Churches in Indonesia (KWI), Parisada Hindu Dharma Indonesia (PHDI), and Representatives of Indonesian Buddhists (Walubi) (Madjid, 2004). The formation of these institutions indicates that the government also pays attention to other religions in Indonesia. Although on the other hand, Indonesia is a Muslim majority country.

If we look back, in the New Order era, the idea of religious harmony in Indonesia was a government program. This indicates that the government guides religious people to live a tolerant, harmonious, and peaceful life under the umbrella of the Indonesian state. The form of harmony itself is outlined in a harmonious trilogy program, namely internal harmony among religious communities and inter-religious harmony with the government (Madjid, 2004; Mubarok, 2014b).

Therefore, it is clear that tolerance and harmony between religious communities are essential. Tolerance between religious communities has become a stronghold in counteracting radicalism and extremism that is rife in society. Understanding and practicing these tolerance values must be conveyed to the public to be understood and implemented in their respective environments.

To explain the nature of religious moderation, many Al-Quran verses explain and order religious moderation in Islam. Among them in surah alBaqarah verse 143:

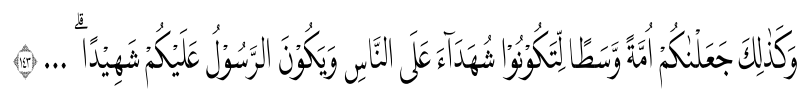

Meaning: And thus we have made you a just community that you will be witnesses over the people, and the Messenger will be a witness over you (Departemen Agama RI, 2010).

In surah al-Furqan verse 67:

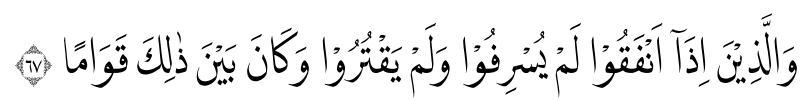

Meaning: And (they are) those who, when they spend, do so not excessively or sparingly but are ever, between that, (justly) moderate (Departemen Agama RI, 2010).

In surah al-Qashash verse 77:

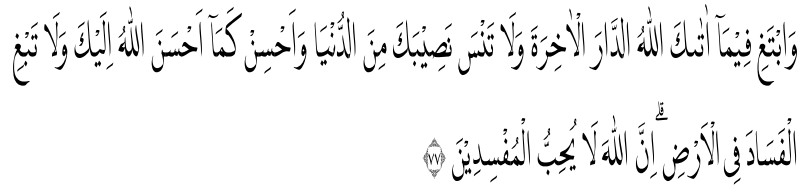

Meaning: But seek, through that which Allah has given you, the home of the Hereafter; and [yet], do not forget your share of the world. And do good as Allah has done good to you. And desire not corruption in the land. Indeed, Allah does not like corrupters" (Departemen Agama RI, 2010).

Then in surah al-Isra' verse 110:

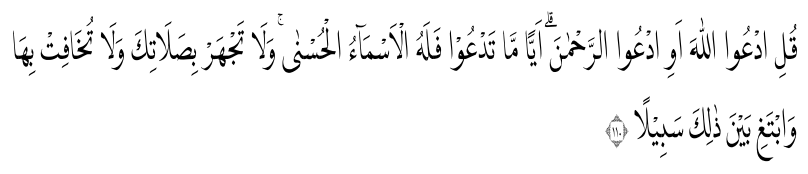


Meaning: Say, "Call upon Allah or call upon the Most Merciful. Whichever (name) you call-to Him belong the best names." And do not recite (too) loudly in your prayer or (too) quietly but seek between that an (intermediate) way (Departemen Agama RI, 2010).

The Word of Allah about tribes and nations is part of the Sunahtullah in Surah al-Hujurat 13:

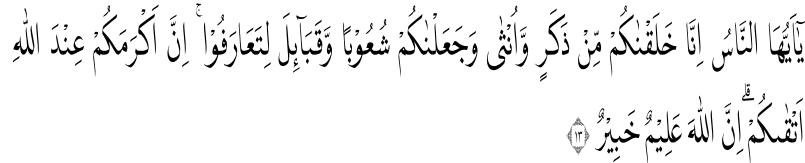

Meaning: O mankind, indeed We have created you from male and female and made you peoples and tribes that you may know one another. Indeed, the most noble of you in the sight of Allah is the most righteous of you. Indeed, Allah is Knowing and Acquainted (Departemen Agama RI, 2010).

Based on the verses above, proving that religious moderation is a way of life that is not excessive. Therefore, excessive behavior is an act of devil that is forbidden by Allah s.w.t. This moderate attitude does not only apply in matters of belief but also in social matters (muamalah) also needs to be done. Therefore, a person has been able to create such things in his life, so he has indirectly embodied religious moderation values in his life. The typology of a person whose life is moderate is that he is always tolerant as if he wants to live with other people who have different opinions and beliefs, and then he resolves a problem peacefully.

Although in the treasures of Classical thought does not recognize the term "moderate,". However, the use and understanding of it usually refer to the equivalent of several Arabic words, including al-tawassut (al-wast) al-qist, al-tawazun, and al-i'tidal. By several Muslims, these words are used to refer to a mode of religion that does not legalize violence as a solution to overcome various theological problems in Islam (Hilmi, 2016). The terms, as mentioned above, have a very close relationship with Islamic moderation. That is, the concept of religious life must be based on the messages of humanity and peace that have been contained in the Al-Quran and Hadith.

Furthermore, the concept of washatiyah seems to be a dividing wall between two opposing things. This enforcer claimed that it did not justify the existence of radical thought in religion, and on the contrary, did not justify the attempt to ignore the content of the Al-Quran as a primary legal basis. Therefore, the concept of this wasathiyah is more likely to be tolerant and not too tenuous in interpreting Islamic teachings (Hilmi, 2016). The concept of moderate life brings religious adherents into a broader dimension. That the life of Muslims consists of two aspects, namely the aqeedah and sharia aspects. The creed issue does not have the term mixing of beliefs (syncretism), but in the social aspect (muamalah), Islam may accept various opinions from other groups as partners in life, nation, and state.

Religious moderation is also an endeavor to preserve Indonesian cultural values. The diversity and diversity of the Indonesian nation contains a very high potential for national disintegration. The diversity and diversity of cultures and religions will be potential if properly maintained and managed. However, it can also be a threat and source of conflict if it is not accompanied by a strong cultural understanding and commitment to maintaining diversity. Indonesian people have a lot of local wisdom (local wisdom), showing that maintaining the nation's integrity is a valuable social capital to view moderate religious attitudes and mindset (Tim Penyusun Kementerian Agama, 2019).

One of the social capital that characterizes the Indonesian nation is the cooperation culture that has long been attached to every social level. Mutual copies a form of manifestation of the spirit of the unity and integrity of the Indonesian nation. This attitude has high moral values, such as togetherness, empathy, mutual assistance, and prioritizing common interests. Attitudes and behavior like this can be found in Indonesian people's activities such as celebrations, social services, agricultural activities, events, disasters of death, and even religious, social activities. This attitude illustrates how the Indonesian people prioritize humanity and equality without leaving differences following the slogan Bhinneka Tunggal Ika (Purwaningsih \& Witro, 2020; Tim Penyusun Kementerian Agama, 2019).

Until today, local wisdom is still preserved, maintained, and become a meeting point for religion and culture in Indonesia is Pancasila. Since the Pancasila was ratified on August 18, 1945, it can be said to be the basis (philosophy) of the state, a way of life, national ideology, and a ligature in 
the life of Indonesian nationality and statehood. Pancasila is a static foundation that unites and, simultaneously, a dynamic star (leitstar), which directs the nation in achieving its goals. In this position the Pancasila is a source of identity, personality, morality, and the direction of the nation's salvation (Latif, 2011).

Thus, in Indonesia's context, Pancasila becomes a meeting point of kalimatun sawa between the religions in the archipelago. When all religions accept the precepts from the Pancasila as a foothold in the nation and state, then the meeting point of kalimatun sawa. So in building a meeting point in diversity, Muslims are always warned by God to preach tolerantly (Mahmud, 2019). Therefore, the manifestation of Pancasila's values must be preserved and implemented in the nation's life and state to unite all differences for the realization of a tolerant, peaceful, just, a prosperous, and blessed community of Allah s.w.t.

\section{Conclusion}

From the explanation and analysis above, conclusions can be drawn. First, religious moderation is part of Islamic teachings. Because the command about religious moderation is found in the Al-Quran. Therefore, religious moderation is an attitude of life in the middle, not leaning left, right, forward and backward, but is in the middle of seeing and resolving a problem. Finally, religious moderation's estuary is to create an atmosphere that is tolerant, peaceful, and harmonious during a multi-religious and multicultural life. Second, religious radicalism is an attitude of life that tends to impose its opinions on others and is willing to win alone. In other words, radicalism is the attitude of someone who wants change through the path of revolution but leaves aside peace. Finally, to achieve a change in the perpetrators of radicalism and extremism must carry out acts of violence to achieve the desired goals.

\section{Thank You Note}

Thanks to all those who contributed to this article so that this article could be completed on time. Friends who help with scientific discussions so that this article's main idea or frame of mind is built. Likewise, with friends who have helped in enriching references from various sources, we thank you. 
‘Asyur, I. (1984). at-Tahrir Wa at-Tanwir. Tunis: adDar Tunisiyyah.

Abby. (2019). Moderasi dan Deradikalisasi Agama. Sejahtera, 22-23.

Al-Qaradhawi, Y. (2014). Islam Radikal: Analisis terhadap Radikalisme dalam Berislam dan Upaya Pemecahannya, (Penerjemah) Hamin Murtadho. Solo: Era Intermedia.

Alam, M. (2017). Studi Implementasi Pendidikan Islam Moderat dalam Mencegah Ancaman Radikalisme di Kota Sungai Penuh Jambi. Jurnal Islamika, 17(2), 17-40.

Departemen Agama RI. (2010). Al-Quran dan Terjemahnya. Bandung: Syaamil Qur'an.

Fauzi, A. (2018). Moderasi Islam, untuk Peradaban dan Kemanusiaan. Jurnal Islam Nusantara, 2(2), 232-244.

Hilmi, D. (2016). Mengurasi Islam Moderat Sebagai Agen Rahmatan Lil 'Alamin. Malang: UIN Maliki Press.

Latif, Y. (2011). Negara Paripurna: Historitas, Rasionalitas, dan Aktualitas Pancasila. Jakarta: PT Gramedia Pustaka Utama.

Madjid, N. dkk. (2004). Fiqih Lintas Agama: Membangun Masyarakat Inklusif-Pluralis. Jakarta: Paramadina.

Mahmud, A. dkk. (2019). Mazhab DufaDufa:Membincang Moderasi Islam Perspektif al-Qur'an. Jakarta: Orbit Publishing.

Margono, S. (2007). Metodologi Penelitian Pendidikan. Jakarta: Rineka Cipta.

Miles, M. B., \& Huberman, A. M. (1984). Qualitative Data Analysis (a Source book of New Methods). Beverly Hills: Sage Publications.

Mubarak, M. Z. (2014). Terorisme di Indonesia: Faktor Keluarga, Teman dan Kegiatan Keagamaan. Dialog, 37(2), 149-164.

Mubarok, H. (2014a). Memperkuat Forum Kerukunan Umat Beragama (FKUB). Dialog, 37(2), 195-205.

Mubarok, H. (2014b). Mencegah Eskalasi Konflik
Keagamaan: Studi Kasus Konflik Natal Bersama di Ungaran, Kabupaten Semarang, Jawa Tengah. Dialog, 37(1), 49-60.

Mulia, M. (2018). Bahaya Radikalisme dan Kekerasan Ekstrismisme. Al-Wardah: Jurnal Kajian Perempuan, Gender Dan Agama, 12(2), 96-106.

Munip, A. (2012). Menangkal Radikalisme Agama di Sekolah. Jurnal Pendidikan Islam, 1(2), 159181. https://doi.org/https://doi.org/10.14421/ jpi.2012.12.159-181

Mussafa, R. A. (2018). Konsep Nilai-nilai Moderasi dalam al-Qur'an dan Implementasinya dalam Pendidikan Agama Islam (Analisis al-Qur'an Surat al-Baqarah 143). UIN Walisongo Semarang.

Purwaningsih, R. F., \& Witro, D. (2020). Islam Nusantara in Slogan Bhinneka Tunggal Ika: Al-Quran Perspective. Cakrawala: Jurnal Studi Islam, 15(1), 1-11. https://doi.org/ 10.31603/cakrawala.v15i1.3301

Rohimah, R. B. (2019). Persepsi Santri tentang Moderasi Islam dan Wawasan Kebangsaan Rt. Bai Rohimah. Hayula, 3(2), 139-156.

Rumadi. (2014). Fikih Hubungan Antarumat Beragama di Indonesia: Fatwa NU, Muhammadiyah dan MUI tentang Relasi Muslim dan Non-Muslim. Dialog, 37(1), 1332.

Sa'adah, A. (2019). Moderasi dan Deradikalisasi Agama. Sejahtera, 12-14.

Saronji, M. (2014). Moderasi dan Deradikalisasi Agama. Sejahtera, 4-6.

Shihab, M. Q. (2016). Yang Hilang Dari Kita: Akhlak. Ciputat: Lentera Hati.

Siradj, S. A. (2013). The sunnî-shî̀ah conflict and the search for peace in Indonesia. Journal of Indonesian Islam, 7(1), 145-164. https:// doi.org/10.15642/JIIS.2013.7.1.145-164

Sugiono. (2009). Metode Penelitian Kuantitatif dan Kualitatif. Bandung: Alfabeta.

Susanto, N. H. (2018). Menangkal Radikalisme 
Atas Nama Agama Melalui Pendidikan Islam Substantif. Nadwa: Jurnal Pendidikan Islam, 12(1), 65-88.

Tim Penyusun Kementerian Agama. (2019). Moderasi Beragama. Jakarta: Badan Litbang dan Diklat Kementerian Agama RI.

Wibowo, A. (2019). Kampanye Moderasi Beragama di Facebook/: Bentuk dan Strategi Pesan. EDUGAMA: Jurnal Kependidikan Dan Sosial Keagamaan, 5(1), 85-103.

Yanti, B. Z., \& Witro, D. (2019). Self Maturity and Tasamuh As a Resolution of Religious Conflicts. Intizar, 25(2), 87-94. https:// doi.org/https://doi.org/10.19109/ intizar.v25i2.5608

Yanti, B. Z., \& Witro, D. (2020). Islamic Moderation As a Resolution of Different Conflicts of Religion. Andragogi: Jurnal Diklat Teknis Pendidikan Dan Keagamaan, 8(1), 446-457. https://doi.org/https://doi.org/10.36052/ andragogi.v8i1.127

Yunus, \& Salim, A. (2018). Eksistensi moderasi islam dalam kurikulum pembelajaran PAI di SMA. Al-Tadzkiyyah: Jurnal Pendidikan Islam, 9(2), 181-194.

Zuhdi, M. H. (2017). Radikalisme Agama dan Upaya Deradikalisasi Pemahaman Keagamaan. Akademika, 22(1), 199-224. 
208 Moderasi Islam Sebagai Solusi ... 
